Open Access, December 2020

p-ISSN : 2087-9423

e-ISSN : 2620-309X
J. Ilmu dan Teknologi Kelautan Tropis, 12(3): 875-884

http://journal.ipb.ac.id/index.php/jurnalikt

DOI: http://doi.org/10.29244/jitkt.v12i3.33243

\title{
STUDI ETNOBOTANI TUMBUHAN MANGROVE DI KUPANG
}

\section{ETHNOBOTANY STUDY OF MANGROVE PLANTS IN KUPANG}

\author{
Anggreini D. N. Rupidara ${ }^{1^{*}}$, Wilson L. Tisera ${ }^{2}$, \& Mellissa E. S. Ledo ${ }^{3}$ \\ ${ }^{1}$ Program Studi Pendidikan Biologi, FKIP, Universitas Kristen Artha Wacana, \\ Kupang 85228, Indonesia \\ ${ }^{2}$ Fakultas Perikanan dan Ilmu Kelautan, Universitas Kristen Artha Wacana, Kupang 85228, Indonesia \\ ${ }^{3}$ Program Studi Pendidikan Biologi, FKIP, Universitas Kristen Artha Wacana, \\ Kupang 85228, Indonesia \\ *E-mail: adn.rupidara@gmail.com
}

\begin{abstract}
The ethnobotanical study is useful for analyzing the quantitative utilization of the species and parts of the mangrove plants, based on the Index of cultural significance (ICS) in the coastal communal. Research sites were Mangrove Tourism Park Oesapa Village, Manikin Beach, Sulamanda Beach Mata Air Village, and Kelapa Tinggi village in Tarus Subdistrict, Oebelo village also Pariti village. The data collection uses field survey methods, observation, and semi-structured interview techniques about plants, plant parts used, and processing methods. Interview results obtained 6 (six) species of major mangrove species: Avicennia marina, Sonneratia alba, Bruguiera parviflora, Ceriops tagal, Rhizophora apiculata, and R. mucronata, and 1 (one) associate mangrove species: Nypa fruticans. Based on ICS values, R. mucronata has the highest ICS value of 708 as an environmental indicator (340), building materials (320) and firewood (48). A. marina, with ICS scores of 114 uses for medicines (108), and S. alba the ICS is 54, especially as betel substitute (12). The community uses the mangroves as environmental indicators, firewood and construction materials, medicines, agricultural activities, related to myths, betel substitutes, making salt, boat materials, syrup, and livestock feed.
\end{abstract}

Keywords: ethnobotany, ICS value, mangrove plants

\begin{abstract}
ABSTRAK
Studi etnobotani berguna untuk menganalisis pemanfaatan jenis dan bagian tumbuhan mangrove secara kuantitatif berdasarkan indeks signifikansi budaya (Index of Cultural Significance) masyarakat pesisir. Penelitian dilakukan di area mangrove Taman Wisata Mangrove Kelurahan Oesapa, Pantai Manikin, Pantai Sulamanda Desa Mata Air, Desa Kelapa Tinggi di Kelurahan Tarus, Desa Oebelo dan Desa Pariti. Pengumpulan data menggunakan metode survei lapangan, observasi dan teknik wawancara semi-terstruktur tentang tumbuhan, bagian tumbuhan yang digunakan dan cara pengolahan terhadap masyarakat yang ada di sekitar hutan mangrove. Hasil wawancara diperoleh bahwa terdapat 6 (enam) spesies mangrove major, yakni: Avicennia marina, Sonneratia alba, Bruguiera parviflora, Ceriops tagal, Rhizophora apiculata, dan R. mucronata, dan 1 (satu) spesies mangrove asosiasi, yakni Nypa fruticans. Berdasarkan nilai Indeks Signifikansi Budaya (ICS), $R$. mucronata memiliki nilai ICS tertinggi (708), yaitu sebagai indikator lingkungan (340) dan bahan bangunan (320). A. marina, nilai ICS 114, terutama pemanfaatannya untuk bahan obat (108), dan $S$. alba bernilai ICS 54, terutama sebagai pengganti sirih (12). Mangrove digunakan sebagai indikator lingkungan, kayu bakar, bahan bangunan, bahan obat, kegiatan pertanian, berkaitan dengan mitos, pengganti sirih, pembuatan garam, bahan perahu, pembuatan sirup dan pakan ternak.
\end{abstract}

Kata kunci: etnobotani, nilai ICS, tumbuhan mangrove

\section{PENDAHULUAN}

Etnobotani adalah ilmu yang mempelajari praktek pemanfaatan tumbuhan yang berguna untuk kepentingan manusia dan lingkungan secara tradisional (Purwanto, 2000; Soekarman \& Riswan, 1992) dan telah berlangsung sejak lama. Studi etnobotani ber- 
manfaat ganda, yaitu menganalisis secara kuantitatif jenis-jenis tumbuhan yang bermanfaat bagi masyarakat baik sosial maupun ekonomi dan perlindungan pengetahuan melalui pelestarian jenis-jenis tumbuhan yang digunakan secara berkelanjutan (Rahayu \& Rustiami, 2017; Suryadharma, 2008). Sudah banyak penelitian mengenai pemanfaatan alam dan tumbuhan mangrove di Nusa Tenggara Timur, namun kajian mengenai etnobotani sebagai kultur/budaya asli kekayaan tradisional masyarakat pesisir hingga saat ini belum banyak dipublikasi.

Ekosistem mangrove yang terletak pada zona intertidal merupakan salah satu potensi bagi kehidupan masyarakat pesisir di provinsi Nusa Tenggara Timur (NTT). Luas ekosistem mangrove di NTT mencapai 17.546,52 Ha dan tersebar di sepanjang garis pantai (Dokumen final rencana zonasi NTT, 2017). Umumnya mangrove di kawasan pesisir masih asri dan masyarakat menjaganya sesuai dengan fungsi sebagai pelindung pantai. Kawasan Teluk Kupang, yang juga ditetapkan sebagai salah satu Taman Wisata Alam Laut (TWAL) di Indonesia merupakan salah satu sumber daya alam hayati yang dikonservasi melalui Undang-undang Nomor 5 Tahun 1990 dan Peraturan Daerah, baik sumber daya dan ekosistemnya termasuk juga fungsi dan peranannya (Bessie et al., 2013).

Mangrove merupakan salah satu ekosistem unik, serta kaya akan bahan organik dan anorganik yang penting bagi kehidupan flora dan fauna yang hidup di area mangrove. Secara fisik, fungsi mangrove adalah untuk menahan abrasi pantai, angin topan, tsunami. Fungsi biologi adalah tempat tinggal bagi satwa liar, feeding ground, tempat pemijahan ikan (spawning ground), serta pengatur iklim mikro (Pramudji, 2003; Lee et al., 2014; Waas \& Nababan, 2010). Oleh karena itu, mangrove merupakan salah satu sumber daya potensial bagi masyarakat di daerah pesisir.

Masyarakat pesisir menggunakan mangrove untuk pemenuhan kebutuhan hidup baik primer maupun sekunder. Secara ekonomis, kegunaan mangrove antara lain untuk kebutuhan rumah tangga berupa bahan makanan, bahan dasar pembuat keripik, tepung (Noor et al., 2006), sebagai bahan bakar bagi dunia industri; bagi dunia kesehatan berupa obat-obatan seperti obat bisul dan obat demam (Ratnasari et al., 2017; Sathe et al., 2012). Fungsi yang menunjang kehidupan, seperti bahan bangunan, upacara adat, budaya, bahan pewarna dan lainnya (Bengen, 2001; Suryadharma, 2008). Kegunaan lain yaitu menggali potensi spesiesspesies tumbuhan mangrove (Eddy et al., 2016) dan bagian yang digunakan (Acharya \& Anshu, 2008) sekaligus menjaga eksistensi kearifan lokal. Berkaitan dengan pemanfaatan spesies mangrove antara lain Rhizophora apiculata, Xylocarpus granatum, Avicennia alba, Ceriops tagal dan Bruguiera cylindrica (Eddy et al., 2018; Leilani et al., 2017; Purwanti, 2016). Penelitian serupa oleh Setiawan (2018) di suku Makassar menggunakan 13 spesies mangrove dalam pemenuhan kebutuhan hidup. Daun dan batang adalah bagian yang paling banyak digunakan dengan persentase masing-masing sebesar $26,32 \%$.

Kajian etnobotani telah berkembang sejak lama dan banyak digunakan dalam mendokumentasikan ilmu pengetahuan lokal asli suatu masyarakat terhadap pemanfaatan tumbuhan yang khas milik kekayaan masyarakat di suatu daerah. Praktek pemanfaatan tumbuhan menggunakan analisis indeks signifikansi budaya/Index Cultural Significance (ICS) oleh masyarakat lokal. Kajian dalam penelitian ini adalah indikasi nilai penting mengenai pemanfaatan tumbuhan mangrove secara tradisional. Mangrove bagi pemenuhan kebutuhan hidup telah berlangsung lama, namun belum banyak dicatat atau didokumentasikan, terutama tentang kajian terhadap spesies-spesies tumbuhan mangrove dan pemanfaatannya di Kupang. Penelitian ini bertujuan untuk mengumpulkan informasi mengenai pemanfaatan tradisional tumbuhan (etnobotani) mangrove oleh masyarakat pesisir di Kupang. 


\section{METODE PENELITIAN}

\subsection{Waktu dan Lokasi}

Penelitian ini dilaksanakan pada bulan September-Oktober 2020 yang didanai oleh Program Penelitian Internal Universitas Kristen Artha Wacana (UKAW) tahun anggaran 2020. Lokasi penelitian berada di enam kawasan hutan mangrove Kota Kupang, yakni Taman Wisata Mangrove Pantai Oesapa Kelurahan Oesapa, Kelurahan Tarus yang meliputi Pantai Manikin, Pantai Sulamanda Desa Mata Air dan Kelapa Tinggi, Pantai Oebelo Desa Oebelo dan Desa Pariti (Figure 1).

\subsection{Pengumpulan Data}

Subjek penelitian adalah masyarakat yang tinggal di sepanjang pesisir kawasan mangrove, yakni: Taman Wisata Mangrove di Pantai Oesapa Kelurahan Oesapa, Pantai Manikin, Pantai Sulamanda Desa Mata Air, Desa Kelapa Tinggi di Kelurahan Tarus, Pantai Oebelo di Desa Oebelo, dan Desa
Pariti Kecamatan Sulamu. Responden dipilih menggunakan metode purposive sampling dengan pertimbangan tertentu, yakni responden dianggap memahami tentang pemanfaatan tumbuhan mangrove dengan memberikan informasi yang tepat terhadap pemanfaatan dan pelestarian tumbuhan mangrove. Responden dalam penelitian ini yakni Kepala Desa/Kelurahan (5 orang) dan tokoh masyarakat (9 orang) serta masyarakat yang menggunakan/memanfaatkan tumbuhan mangrove (14 orang).

\subsection{Metode Penelitian}

Penelitian ini menggunakan metode survei dengan pendekatan analisis deskriptif. Data primer dikumpulkan melalui observasi dan teknik wawancara semi-terstruktur yaitu wawancara menggunakan pedoman garis besar pertanyaan-pertanyaan yang berkaitan tentang tumbuhan, bagian tumbuhan yang dimanfaatkan dan cara pengolahan oleh masyarakat di daerah pesisir.
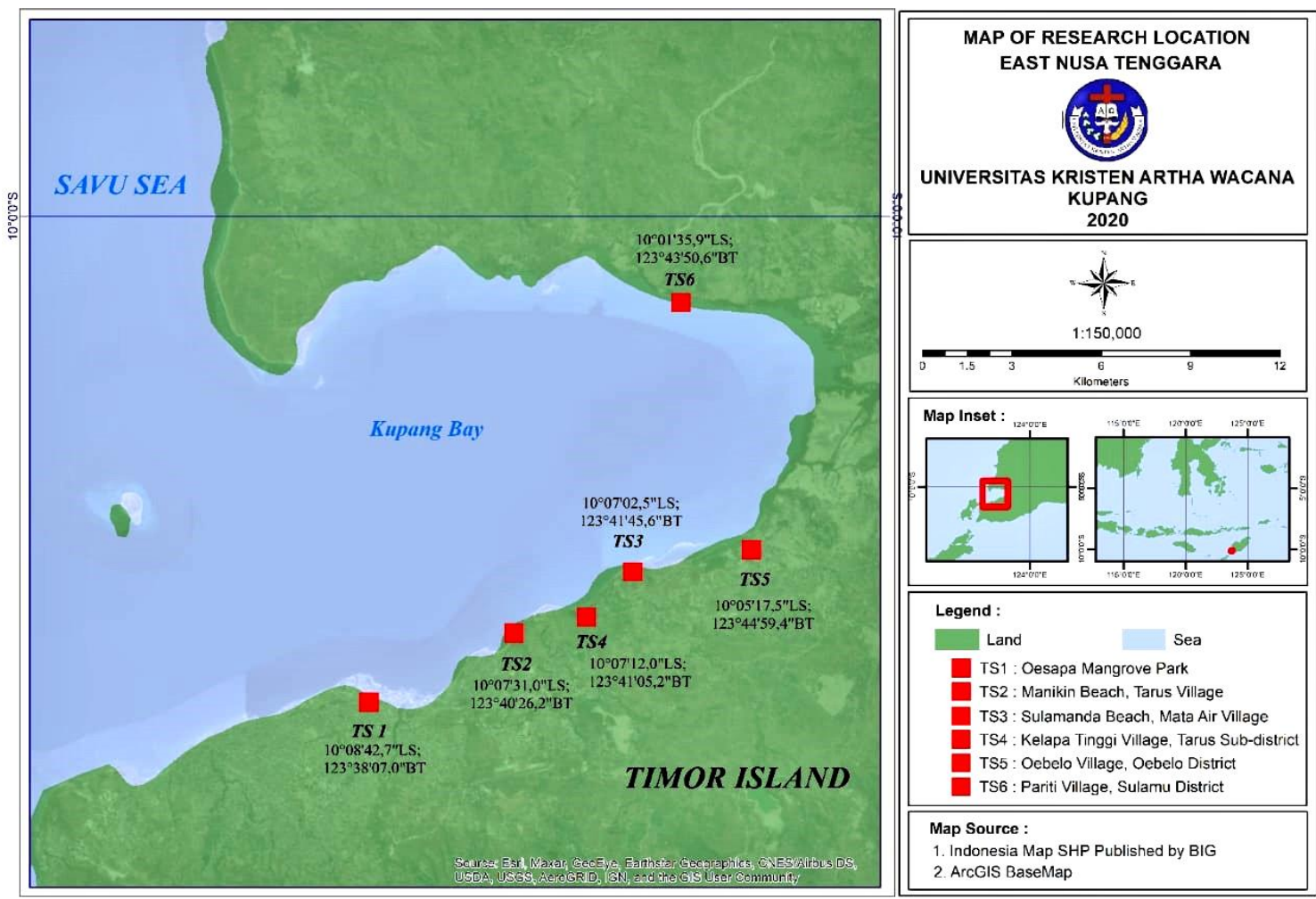

Figure 1. Map of Research Location. 
Data yang dikumpulkan meliputi spesies tumbuhan mangrove yang dimanfaatkan secara tradisional oleh masyarakat pesisir hutan mangrove dengan mencatat nama lokal tumbuhan, bagian tumbuhan yang digunakan, proses pengolahan dan pemanfaatannya

\subsection{Analisis Data}

Data dianalisis dengan menggunakan ICS. Indeks signifikansi budaya adalah analisis etnobotani kuantitatif yang menunjukkan pentingnya spesies tumbuhan berdasarkan kebutuhan masyarakat yang meliputi 3 (tiga) aspek, yaitu nilai kegunaan (q), nilai intensitas (i), dan nilai eksklusivitas (e). indeks sigifikansi budaya dihitung berdasarkan rumus (Turner, 1988):

$$
\begin{aligned}
\mathrm{ICS}= & \sum_{i}^{n}(\mathrm{q} 1 \mathrm{xi} 1 \mathrm{xe} 1) \mathrm{n} 1+(\mathrm{q} 1 \mathrm{xi} 1 \mathrm{xe} 1) \\
& n 2 \ldots+(\mathrm{q} 1 \mathrm{xi} 1 \mathrm{xe} 1) n \quad \ldots \ldots \ldots(1)
\end{aligned}
$$

Keterangan: ICS adalah jumlah perhitungan pemanfaatan jenis tumbuhan dari 1 sampai dengan $n$, di mana $n$ adalah jumlah pemanfaatan ke- $n, I$ adalah nilai intensitas, $Q$ adalah nilai kualitas yang dihitung menggunakan skor atau skala untuk nilai kualitas dari suatu spesies tumbuhan. Skor yang digunakan adalah $5=$ makanan pokok; $4=$ makanan sekunder + bahan utama; 3= makanan lain + bahan sekunder + obat-obatan; $2=$ ritual, mitologi, rekreasi, dll., dan $1=$ hanya pengenalan, $e$ adalah nilai eksklusivitas.

\section{HASIL DAN PEMBAHASAN}

\subsection{Tumbuhan Mangrove yang Dimanfaatkan}

Dari hasil wawancara di area Taman Wisata Mangrove Kelurahan Oesapa, Pantai Sulamanda Desa Mata Air, Desa Kelapa Tinggi di Kelurahan Tarus, Desa Oebelo dan Desa Pariti terdapat 7 jenis mangrove yakni: A. marina, S. alba, B. parviflora, C. tagal, $R$. apiculata, dan $R$. mucronata sebagai mangrove major dan spesies Nypa fruticans sebagai spesies asosiasi. Mangrove major adalah spesies yang hidup di habitat mangrove dengan membentuk tegakan murni, memiliki organ adaptif khusus (bentuk akar dan viviparitas), dapat mengontrol garam oleh mekanisme fisiologisnya terhadap lingkungan mangrove (Tomlinson, 1986).

Dalam wawancara dengan sebagian besar responden di Kelurahan/Desa lokasi penelitian menyatakan bahwa mereka memanfaatkan mangrove baik secara langsung maupun tidak langsung, diantaranya sebagai bahan obat, makanan maupun kebutuhan sehari-hari lainnya, karena mangrove merupakan sumber daya alam yang penting bagi masyarakat pesisir (Kinasih \& Purnaweni, 2019; Soedarmo, 2018). Beberapa responden menyatakan bahwa tidak dapat menggunakan tumbuhan yang hidup di area mangrove, karena adanya peraturan desa yang melarang masyarakat untuk mengambil dan memanfaatkan tumbuhan mangrove untuk keperluan sehari-hari. Namun ada beberapa pemanfaatan yang terdokumentasi (Table 1).

Kebutuhan sekunder, yakni sebagai kayu bakar, bahan bangunan dan bahan pembuatan badan perahu. Kegunaan lainnya adalah sebagai bahan obat, pakan ternak, bahan sirup (Sukardjo \& Akhmad, 1982; Paramita, 2012), serta pengganti sirih. Bagian tumbuhan mangrove yang digunakan adalah, daun, ranting, batang, kulit batang, buah dan akar (Figure 2). Sebagian kecil masyarakat pesisir di Nusa Tenggara Timur masih percaya ada kaitan antara mangrove dengan mitos dan adat budayanya, seperti untuk memanggil hujan dan perlindungan diri.

Sebagai upaya konservasi mangrove, masyarakat pesisir di lokasi penelitian tidak memanfaatkan tumbuhan mangrove secara eksesif. Mereka memahami fungsi ekologis mangrove sebagai indikator lingkungan, penahan abrasi, banjir, gelombang laut dan habitat sumber daya ikan. Fungsi ekologis ini sering disebut oleh masyarakat menjaga lingkungan. Kelompok tumbuhan $R$. mucronata, A. marina, dan S. alba banyak di- 
Table 1. Traditional Usage of Mangrove Plants.

\begin{tabular}{|c|c|c|c|c|c|}
\hline No. & $\begin{array}{l}\text { Scientific } \\
\text { name }\end{array}$ & $\begin{array}{l}\text { Local } \\
\text { name }\end{array}$ & $\begin{array}{l}\text { Part plant } \\
\text { to use }\end{array}$ & Processing & Utilization \\
\hline \multirow[t]{5}{*}{1} & A. marina & Api-api & Leaf & Boiled and eaten & Burns medicine \\
\hline & & & Leaf & $\begin{array}{l}\text { Boiled and then eaten } \\
\text { or for bathing }\end{array}$ & $\begin{array}{l}\text { Internal } \\
\text { medicine }\end{array}$ \\
\hline & & & $\begin{array}{l}\text { Leaf and } \\
\text { twigs }\end{array}$ & $\begin{array}{l}\text { The leaves are burned } \\
\text { together with the } \\
\text { branches to cause } \\
\text { smoke }\end{array}$ & $\begin{array}{l}\text { Mosquito } \\
\text { repellent }\end{array}$ \\
\hline & & & Leaf & $\begin{array}{l}\text { The leaves are fed to } \\
\text { livestock }\end{array}$ & Animal feed \\
\hline & & & Bark & Boiled then drunk & $\begin{array}{l}\text { Traditional } \\
\text { herbal medicine }\end{array}$ \\
\hline \multirow[t]{4}{*}{2} & S. alba & Bo'ak & $\begin{array}{l}\text { Leaf and } \\
\text { root }\end{array}$ & $\begin{array}{l}\text { Cutting off root/leaf } \\
\text { and chewing in place of } \\
\text { betel-leaf }\end{array}$ & $\begin{array}{l}\text { substitute for } \\
\text { betel }\end{array}$ \\
\hline & & & Fruit & $\begin{array}{l}\text { Ripe fruit is blended, } \\
\text { boiled, added with } \\
\text { sugar and citric acid to } \\
\text { make syrup }\end{array}$ & Syrup \\
\hline & & & Fruit & & $\begin{array}{l}\text { Myth: Summon } \\
\text { the rain }\end{array}$ \\
\hline & & & Fruit & & $\begin{array}{l}\text { The myth of } \\
\text { mangrove fruit } \\
\text { as personal } \\
\text { protection }\end{array}$ \\
\hline \multirow[t]{3}{*}{3.} & R. mucronata & Bakau & Tree & $\begin{array}{l}\text { Coastal protection, by } \\
\text { resisting currents and } \\
\text { waves, as well as } \\
\text { flooding }\end{array}$ & $\begin{array}{l}\text { Environmental } \\
\text { functions such } \\
\text { as abrasion and } \\
\text { erosion } \\
\text { resistance }\end{array}$ \\
\hline & & & Stem & Cut down & firewood \\
\hline & & & Stem & Cut down & $\begin{array}{l}\text { Building } \\
\text { material }\end{array}$ \\
\hline
\end{tabular}

Primary Data (2020)

temukan di lokasi penelitian. Penggunaan kayu ketiga jenis mangrove tersebut merupakan kebutuhan paling tinggi karena struktur kayu yang keras, awet (terendam dalam air) serta tegak (Dahdouh-Guebas et al., 2000; Huxham et al., 2017; Leilani et al., 2017; Purwanti, 2016) (Table 2).

Masyarakat di Kelurahan Oesapa, memakai daun A. marina yang dikenal sebagai Api-api untuk keperluan bahan obat.
Pengolahan daun Api-api dapat dilakukan dengan beberapa cara, yaitu dimakan, direbus dan diminum airnya, bahkan digunakan juga untuk mandi. Bagian tumbuhan yang juga dimanfaatkan adalah kulit batang sebagai bahan obat. Masyarakat Desa Kelapa Tinggi memanfaatkan daun dan ranting sebagai obat nyamuk, dengan cara dibakar bersamaan hingga mengeluarkan asap dengan bau yang khas untuk mengusir nyamuk. Masyarakat di 

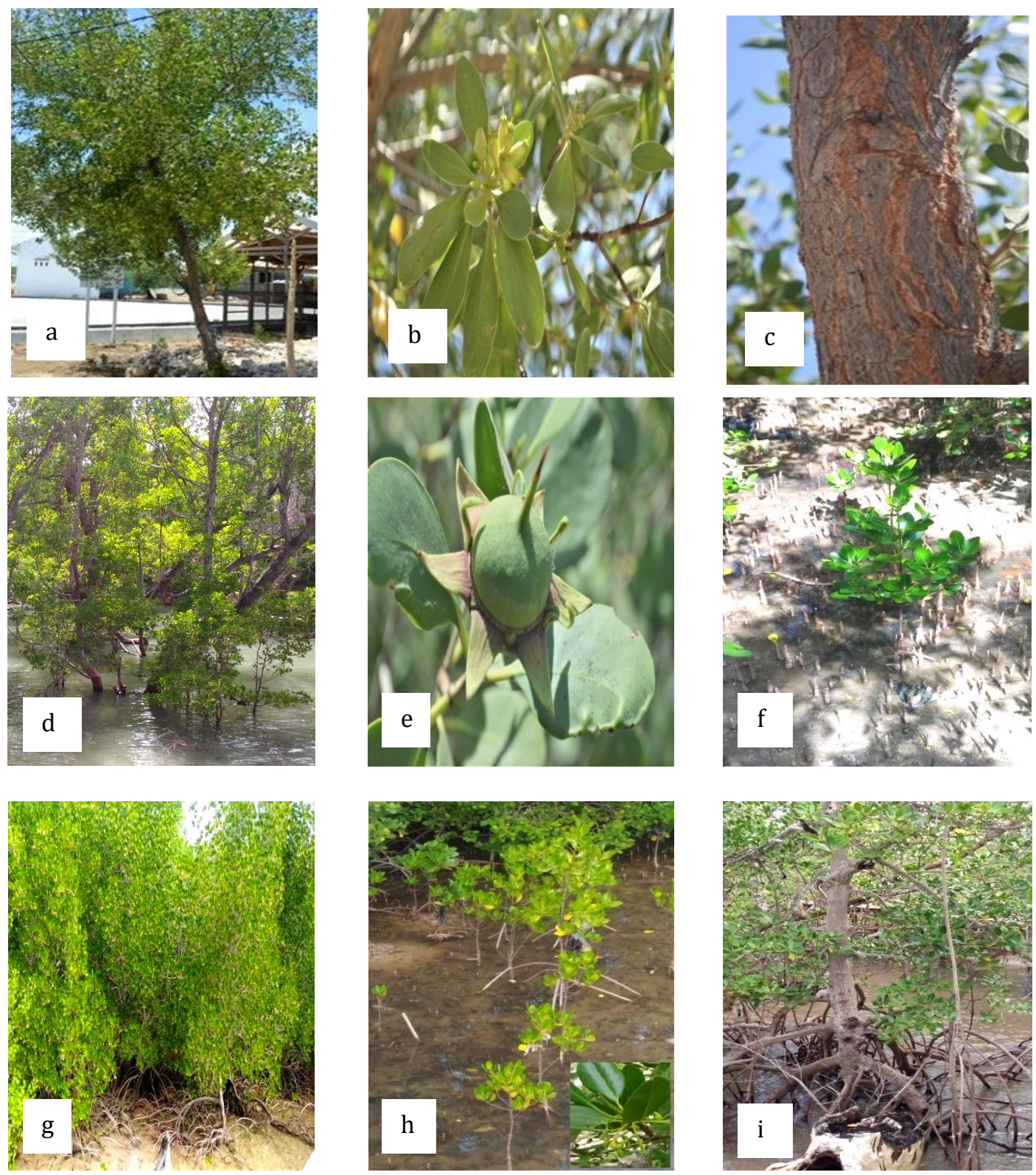

Figure 2. Parts of mangrove plants that are used by the coastal communities, (a.b.c) A. marina; (d.e.f.) S. alba; (g.h.i) R. mucronata.

Desa Oebelo lebih banyak mengambil kayu untuk membuat pagar dan kayu bakar (Dahdouh-Guebas et al., 2000; Huxham et al., 2017). Daun A. marina dan juga S. alba dimanfaatkan sebagai pakan ternak sapi, sebagaimana hal yang sama juga dilakukan oleh masyarakat pesisir di Desa Cimanuk Jawa Barat (Sukardjo \& Akhmad, 1982; Paramita, 2012).

Bagian yang diambil pada $S$. alba atau disebut Bo'ak adalah buahnya untuk pembuatan sirup. Bagian lain yang sering dimanfaatkan adalah akar muda oleh beberapa adat budaya di Desa Pariti, sebagai pengganti sirih. Daun Bo'ak dan Api-api digunakan dalam bahan obat. Pemanfaatan lain tidak banyak dilakukan oleh masyarakat pesisir karena kurangnya pengetahuan, namun daun dan buah Bo'ak menurut Paramita (2012) dapat langsung dikonsumsi atau dimasak sebagai sayur.

Adapun pemanfaatan sebagai bahan 
Table 2. Index of Cultural Significance (ICS) Utilization of Mangrove Plants in Coastal Communities.

\begin{tabular}{llllllll}
\hline $\begin{array}{c}\text { Spesies } \\
\text { Mangrove }\end{array}$ & \multicolumn{1}{c}{ Utilization } & $q$ & $i$ & $e$ & $U V s$ & ICS & $\begin{array}{c}\text { Total } \\
\text { ICS }\end{array}$ \\
\hline A.marina & medicine & 3 & 3 & 2 & 6 & 108 & 114 \\
& Animal feed & 3 & 2 & 1 & 1 & 6 & \\
S. alba & Substitution of betel & 3 & 2 & 1 & 2 & 12 & 54 \\
& Syrup & 3 & 3 & 1 & 1 & 9 & \\
& Animal feed & 3 & 2 & 1 & 1 & 6 & \\
& Myth (magical) and religious & 3 & 3 & 1 & 3 & 27 & \\
& Environmental indicators & 2 & 5 & 2 & 17 & 340 & 708 \\
& Firewood & 4 & 2 & 0.5 & 12 & 48 & \\
& Building material & 4 & 4 & 2 & 10 & 320 & \\
\hline
\end{tabular}

Primary Data (2020)

obat sudah dilakukan sejak beberapa generasi, hal ini merupakan pengetahuan lokal atau etnobotani lokal yang dimiliki warga yang tinggal di dekat area hutan mangrove, seperti obat luka, obat penyakit dalam dan obat nyamuk yang diteruskan oleh orang tua kepada anak-anak. Adapun pemanfaatan sebagai bahan makanan jarang sekali dilakukan sejak adanya peraturan Desa, namun pengetahuan seperti pembuatan sirup diperoleh dari penyuluhan oleh instansi pemerintah. Menurut beberapa tokoh masyarakat, mangrove yang ada sekarang merupakan hasil penanaman dalam upaya perlindungan karena pernah terjadi banjir besar di tahun 1980-an. Oleh karena itu dibuat peraturan Desa yang melarang masyarakat untuk menggunakan tumbuhan secara besar-besaran.

Dari ketiga spesies mangrove yang paling banyak ditemukan di lokasi penelitian dan yang dimanfaatkan oleh masyarakat pesisir, secara keseluruhan memiliki kategori indeks signifikansi budaya (ICS) yang sangat tinggi ditinjau dari pemanfaatannya (Table 2). Mangrove menyediakan berbagai manfaat bagi ekosistem dan bagi masyarakat, namun yang harus diperhatikan selain pemanfaatannya juga dampak terhadap ekosistem pesisir secara antropogenik (Rivera-Monroy et al., 2017). Adapun nilai ICS dapat dikategorikan sebagai berikut: nilai 1-10 adalah sangat ren- dah, 10-20 dikategorikan rendah, 20-50 adalah sedang, 50-100 dikategorikan sebagai tinggi dan > 100 dikategorikan sangat tinggi (Silalahi et al., 2018).

Berdasarkan hasil perhitungan ICS, diperoleh bahwa pemanfaatan tumbuhan mangrove sangat tinggi atau kategori $>100$ pada tumbuhan $R$. mucronata dengan nilai ICS paling tinggi sebesar 708, dan A. marina memiliki nilai ICS sebesar 114. $R$. mucronata memiliki nilai ICS sebesar 340 sebagai indikator lingkungan yang oleh masyarakat dianggap bermanfaat sebagai pelindung dari bahaya banjir, dan selain itu bermanfaat sebagai bahan bangunan (ICS 320). A. marina paling banyak dimanfaatkan sebagai bahan obat (ICS 108), dengan cara pengolahan yang sederhana, yakni dimakan secara langsung, dan direbus kemudian air rebusan digunakan untuk mandi yang bermanfaat dalam mengobati berbagai penyakit, serta sebagai pakan ternak (ICS 6). Indeks ICS kategori tinggi (50-100) dijumpai pada jenis tumbuhan $S$. alba sebesar 54, terutama dimanfaatkan sebagai pengganti sirih (ICS 12).

Akumulasi nilai indeks signifikansi budaya (ICS) tumbuhan mangrove oleh masyarakat pesisir, terutama digunakan sebagai indikator lingkungan, bahan bangunan, bahan obat, kayu bakar, nilai religius dan mitos, 
pengganti sirih, dan juga digunakan sebagai pakan ternak. Berdasarkan nilai kualitas, intensitas dan eksklusivitas, masyarakat pesisir secara tidak langsung memahami nilai penting dalam pemanfaatan tumbuhan mangrove (Age et al., 2020; Rahayu et al., 2012).

\section{KESIMPULAN}

Di lokasi penelitian terdapat enam spesies mangrove major, yaitu: A. marina, $S$. alba, B. parviflora, C. tagal, R. apiculata, dan $R$. mucronata, dan satu spesies asosiasi mangrove, yaitu $N$. fruticans. $R$. mucronata memiliki nilai Indeks Signifikansi Budaya (ICS) sangat tinggi, yaitu sebesar 708, diikuti oleh A. marina dengan nilai 114 , dan S. alba sebesar 54 dengan kategori tinggi. Bagian tumbuhan mangrove yang digunakan adalah akar, batang, kulit batang, ranting, daun dan buah. Nilai ICS dalam pemanfaatan tumbuhan mangrove, yaitu sebagai indikator lingkungan, bahan bangunan, bahan obat, kayu bakar, nilai religius/mitos, pengganti sirih, dan pakan ternak.

\section{UCAPAN TERIMAKASIH}

Terima kasih kepada Lembaga Penelitian Universitas Kristen Artha Wacana yang mendanai penelitian ini melalui Program Penelitian Unggulan Universitas TA. 2020. Terima kasih kepada Khaterina Manikin, Ocrsyn Ludji Lobo, Chyntia Kore, Sarah Nenometa, dan Chyntia Taebenu yang telah berpartisipasi dalam proses wawancara dengan responden.

\section{DAFTAR PUSTAKA}

Acharya, D. \& S. Anshu. 2008. Indigenous Herbal Medicines: Tribal Formulations and Traditional Herbal Practices. Aavishkar Publishers Distributor, Jaipur. 440 p.

Age, D.L., A.Ch. Hendrik, \& A.D.N. Rupidara. 2020. Ethnobotany study of lontar tree (Borassus flabellifer L.) at
Raijua Island. IOP Conf. Ser.: Mater. Sci. Eng. 823 012048. 7 p. https://doi.org/10.1088/1757899X/823/1/012048

Bengen, D.G. 2002. Ekosistem dan Sumberdaya Alam Pesisir dan Laut serta Prinsip Pengelolaannya. Pusat Kajian Sumberdaya Pesisir dan Lautan IPB, Bogor. 66 p.

Bessie, D.M., J.N. Schaduw, E. Reppie, \& M.T. Lasut. 2013. Community structure of mangrove at Marine Tourism Park of Kupang Bay, East Nusa Tenggara Struktur komunitas mangrove di Taman Wisata Alam Laut Teluk Kupang, Nusa Tenggara Timur. Aquatic Science \& Management, Edisi Khusus, 1: 3-9. https://doi.org/10.35800/jasm.0.0.201 3.2270

Dahdouh-Guebas, F., C. Mathenge, J.G. Kairo, \& N. Koedam. 2000. Utilization of mangrove wood products around mida creek (Kenya) amongst subsistence and commercial users. Econ. Bot., 54: 513-527. https://doi.org/10.1007/BF02866549

Eddy, S., D. Rosanti, \& M. Falansyah. 2018. Keragaman spesies dan etnobotani tumbuhan mangrove di Kawasan Hutan Lindung Air Telang Kabupaten Banyuasin. Prosiding Seminar Nasional Sains dan Teknologi 20 Oktober 2018 Fakultas Sains dan Teknologi, UIN Raden Fatah Palembang, Vol 1 No. 1: 4-12 pp.

Eddy, S., M.R. Ridho, I. Iskandar, \& A. Mulyana. 2016. Community based mangrove forests conservation for sustainable fisheries. J. Silvikultur Tropika, 07(3): S42-S47.

https://doi.org/10.31219/osf.io/x659w

Huxham M., A. Dencer-Brown, K. Diele, K. Kathiresan, I. Nagelkerken, \& C. Wanjiru. 2017 Mangroves and People: Local Ecosystem Services in a Changing Climate. In: RiveraMonroy V., S Lee, E. Kristensen, R. 
Twilley. (eds) Mangrove Ecosystems: A Global Biogeographic Perspective. Springer, Cham. 245-274 pp. https://doi.org/10.1007/978-3-31962206-4_8

Kinasih, P.I. \& H. Purnaweni. 2019. Pemanfaatan Mangrove Untuk Pemberdayaan Masyarakat Pesisir. Proceeding Conference Public Administration and Society, Fakultas Ilmu Sosial dan Ilmu Politik Unversitas Diponegoro, Tembalang, Semarang. 30 Oktober 2019. 71-78 pp.

Lee, S.Y., J.H. Primavera, F. DahdouhGuebas, K. McKee, J.O. Bosire, S. Cannicci, K. Diele, F. Fromard, N. Koedam, C. Marchand, I. Mendelssohn, N. Mukherjee, \& S. Record. 2014. Ecological role and services of tropical mangrove ecosystems: a reassessment. Global Ecology and Biogeography, (Global Ecol. Biogeogr.), 23: 726-743. https://doi.org/10.1111/geb.12155

Leilani, I., T.M. Rizki, Sari, \& D.M. Sari. 2017. Studi etnobotani pada hutan mangrove di Kota Padang dan Kota Pariaman. J. Bioscience, 1(2): 87-91. https://doi.org/10.24036/bsc.v1i2.808 4

Noor, Y.R., M. Khazali, \& I.N.N. Suryadiputra. 2006. Panduan pengenalan mangrove di Indonesia. Ditjen PHKA dan Wetlands International Indonesia Programme, Bogor. 220 p.

Paramita, O. 2012. Pemanfaatan berbagai jenis buah mangrove sebagai sumber pangan berkarbohidrat tinggi. Seminar Nasional 2012 Peningkatan Kompetensi Guru dalam Menghadapi UKG Jurusan PTBB FT UNY, 15 Desember 2012. 7(1): 365-373 pp.

Peraturan Daerah Provinsi Nusa Tenggara Timur Nomor 4 Tahun 2017 Tentang Rencana Zonasi Wilayah Pesisir Dan Pulau-Pulau Kecil Provinsi Nusa
Tenggara Timur Tahun 2017-2037. $512 \mathrm{p}$.

Pramudji. 2003. Keanekaragaman flora di hutan mangrove kawasan pesisir Teluk Mandar, Polewali, Provinsi Sulawesi Selatan: Kajian Pendahuluan. J. Biota, 8(3): 135-142. https://doi.org/10.24002/biota.v8i3.28 57

Purwanti, R. 2016. Studi etnobotani pemanfaatan jenis-jenis mangrove sebagai tumbuhan obat di Sulawesi. Prosiding Seminar Nasional Tumbuhan Obat Indonesia Ke-50. 340-348 pp. https://doi.org/10.25026/mpc.v3i2.13 1

Purwanto, Y. 2000. Etnobotani dan konservasi plasma nutfah hortikultura : peran sistem pengetahuan lokal pada pengembangan dan pengelolaannya. Prosiding Seminar Hari Cintapuspa dan Satwa Nasional. 308-322 pp.

Rahayu, M., Y. Purwanto, \& S. Susiarti. 2012, Nilai kepentingan budaya keanekaragaman jenis tumbuhan berguna di Hutan Dataran Rendah Bodogol, Sukabumi, Jawa Barat* [Index Cultural Significance Of Useful Plants Diversity In Bodogol Lowland Forest, Sukabumi, West Java]. Berita Biologi, 11(3): 313-319. https://doi.org/10.14203/beritabiologi. v11i3.501

Rahayu M. \& H. Rustiami. 2017. Etnobotani masyarakat samawa Pulau Sumbawa. Scripta Biologica, 4 (4): 235-245. https://doi.org/10.20884/1.sb.2017.4.4 .605

Ratnasari, Fahrizal., \& M. Dirhamsyah. 2017. Pemanfaatan vegetasi mangrove di Pulau Padang Tikar Kecamatan Batu Ampar Kabupaten Kubu Raya. J. Tengkawang, 7(2): 110-115. http://doi.org/10.26418/jt.v7i2.23783

Rivera-Monroy V.H., S. Lee, E. Kristensen, R. Twilley 2017. Advancing 
Mangrove Macroecology. In: RiveraMonroy V.H,. S. Lee, E. Kristensen, R. Twilley. (eds) Mangrove Ecosystems: A Global Biogeographic Perspective. Springer, Cham. 347-381 pp.

https://doi.org/10.1007/978-3-31962206-4_11

Sathe, S., R. Lawate, \& L. Bhosale. 2012. Ethnobotanical and fishery related studies on mangrove ecosystem with special reference to Malvan Tahsil of Sindhudarg District Maharashtr. Trends and Fisheries Research, 1(3): 9-14.

http://sciencejournal.in/data/documen ts/TFR-3-3.pdf

Setiawan, H. 2018. Kajian etnobotani mangrove masyarakat adat makassar Di Pulau Tanakeke Kabupaten Takalar Provinsi Sulawesi Selatan. Di akses 13 Juni 2020 dari https://www.researchgate.net/publicat ion $/ 323471417$

Silalahi M., Nisyawati, E.B. Waluyo, \& W. Musataqim. 2018. Etnomedisin tumbuhan obat oleh subetnis Batak Phakpak di Desa Surung Mersada, Kabupaten Phakpak Bharat, Sumatera Utara J. ILMU DASAR, 19(2): 77-92. https://doi.org/10.19184/jid.v19i2.701 7

Soedarmo, S.P.K. 2018. Pelestarian Hutan Mangrove dan Peran Serta Masyarakat Pesisir. Penerbit Undip Press Semarang. 191 p.
Soekarman, \& S. Riswan. 1992. Status Pengetahuan Etnobotani di Indonesia. Seminar dan Lokakarya Nasional Etnobotani; Cisarua-Bogor, 19-20 Februari 1992. Bogor: Departemen Pendidikan dan Kebudayaan RI, Departemen Pertanian RI, LIPI, Perpustakaan Nasional RI. 1-7 pp.

Suryadharma, I.G.P. 2008. Diktat kuliah etnobotani. Universitas Negeri Yogyakarta. $61 \mathrm{p}$.

Tomlinson, P.B. 1986. The botany of mangroves. London: Cambridge University Press, Cambridge. 413 p.

Turner, N.J. 1988. The Importance of a Rose: Evaluation the Cultural Significance of Plants in Thompson and Lillooet Interior Salish. American Anthropologist, 90(2): 272-290. https://doi.org/10.1525/aa.1988.90.2.0 $2 \mathrm{a} 00020$

Undang-Undang Republik Indonesia No. 5 Tahun 1990 tentang Konservasi Sumber Daya Alam Hayati dan Ekosistemnya. 28 p.

Waas, H.J.D. \& B. Nababan. 2010. Pemetaan dan analisis index vegetasi mangrove di Pulau Saparua, Maluku Tengah. $J$. Ilmu dan Teknologi Kelautan Tropis, 2(1): 50-58.

https://repository.ipb.ac.id/handle/123 $456789 / 53410$

Received : 18 November 2020
Reviewed $: 23$ November 2020
Accepted $: 20$ December 2020 